\title{
RAIMON PANIKKAR: A ARRISCADA AVENTURA NO SOLO SAGRADO DO OUTRO
}

(Raimon Panikkar: the risky adventure on the sacred ground of the other)

\author{
Faustino Teixeira *
}

RESUMO: Não há como falar em diálogo inter-religioso sem lembrar o nome desse grande buscador que foi Raimon Panikkar (1918-2010). Foi um pioneiro na abertura dialogal, abrindo pistas inovadoras na reflexão sobre o tema. Sua contribuição não se resume ao campo teórico, mas também ao exercício vital de hospitalidade, doação e entrega ao Mistério que habita no solo sagrado do outro. Esse artigo tem como objetivo apresentar o seu itinerário de vida e reflexão, sinalizando alguns dos traços mais significativos de seu original pensamento.

PALAVRAS-CHAVE: Diálogo, Cristianismo, Hinduísmo, Mística, Alteridade.

\begin{abstract}
One cannot speak of interreligious dialogue without remembering the name of this great investigator Raimon Panikkar (1918-2010). He was a pioneer in the beginning talks, opening innovative tracks in the reflection on the subject. His contribution is not limited to the theoretical field, but also extends to the vital exercise of hospitality, donation and surrender to the Mystery that inhabits the sacred ground of the other. The objective of this article is to present his itinerary of life and reflection, pointing out some of the most significant traces of his original thought.
\end{abstract}

KEY-WORDS: Dialogue, Christianity, Hinduism, Mystic, Alterity.

* Universidade Federal de Juiz de Fora. Artigo submetido a avaliação no dia 29/09/2010 e aprovado para publicação no dia 15/10/2010. 


\section{Introdução}

$\mathrm{R}$ aimon Panikkar (1918-2010) foi um dos mais ousados e singulares buscadores do diálogo. Sem dúvida alguma, um pioneiro no campo do diálogo das religiões, que abriu pistas e caminhos novidadeiros para a reflexão e exercício de uma dinâmica inovadora na relação do cristianismo com as diversas tradições religiosas, e em particular com o hinduísmo. Sua longa vida foi marcada pelo dom da abertura e do aprendizado com o outro. Uma vida "caleidoscópica", como assinalou o amigo Miquel Siguan, também estudioso do místico catalão. Um traço peculiar de Panikkar, enquanto pensador, é a criatividade e o manejo original de lidar com as palavras. Com seu singular jargão, Panikkar favorece a viagem ao mundo sagrado do outro, desvendando caminhos, quebrando preconceitos e suscitando uma admiração que transforma o horizonte da autocompreensão. Vale bem para Panikkar, o que David Tracy falou sobre a difícil arte da conversação inter-religiosa, esse "inquietante lugar" que provoca mudanças na autocompreensão do sujeito ao levar realmente a sério as posições do outro ${ }^{1}$.

\section{Traços biográficos}

A sua vida familiar já reflete uma dinâmica dialogal e multicultural. Nasce em Barcelona, em novembro de 1918, numa típica família burguesa. Sua mãe, Carmen Alemany, era catalã e profundamente católica. Uma mulher marcada por grande abertura, que cultivava a música e as artes; seu pai, Ramun Panikkar ${ }^{2}$, um hindu de origem aristocrática e passaporte britânico. O casal teve quatro filhos. Panikkar fala dos pais com carinho. Recorda a gentileza de seu pai e o caráter decisivo de sua mãe. É dela que recebe uma singular educação católica, que o levou a enamorar-se, desde cedo, da pessoa de Jesus Cristo. Essa marca multicultural de sua vida vai ser por ele lembrada em passagens de sua reflexão: "Havia uma harmonia profunda entre meu pai e minha mãe, sendo de duas tradições diferentes" ${ }^{\prime 3}$. No âmbito dessa experiência familiar, de compreensão e respeito, é que se gestou uma perspectiva distinta para o itinerário de Panikkar. Ele assinala que esse aprendizado vem do início de sua vida: "Aquelas dimensões da fé cristã que me permitiam viver em paz com a outra parte de meu ser: a

${ }^{1}$ D. TRACY, Pluralidad y ambigüedad, Madrid: Trotta, 1997, p. 142.

${ }^{2} \mathrm{O}$ nome Panikkar era um título nobiliário malabar.

${ }^{3}$ V.P. PRIETO, Más allá de la fragmentación de la teología. El saber y la vida: Raimon Panikkar, Valencia: Tirant lo Blanch, 2008, p. 41. 
discreta influência de meu pai, que me cantava e explicava o Bhagavad Gita, que me fornecia os fundamentos do sânscrito e me envolvia numa não-confessional atmosfera hindu" .

A questão religiosa foi marcante na vida de Panikkar. Admite em entrevista concedida a Gwendoline Jarczyk que esteve sempre "preocupado por aquilo que hoje se define como o problema religioso" ${ }^{\prime 5}$. Sua formação inicial aconteceu com os jesuítas de Barcelona, no colégio Santo Inácio de Sarriá. Os estudos universitários foram realizados nas Universidades de Barcelona, Bonn e Madri. Em 1946, ano de sua ordenação sacerdotal, doutorou-se em filosofia e letras na Universidade de Madri, com uma tese sobre $O$ conceito de natureza. Análise histórica e metafísica de um conceito ${ }^{6}$. O segundo doutorado veio em 1958, em Ciências Químicas, defendido na mesma Universidade, com uma tese sobre alguns problemas limítrofes entre ciência e filosofia. Sobre o sentido da ciência natural ${ }^{7}$. Três anos depois, em Roma, defende seu doutorado, na Universidade Lateranense, com uma tese que tratou o tema do Cristo desconhecido do hinduísmo. O orientador inicial foi Pietro Parente, que deixou o trabalho para outro professor da Lateranense, assim que se tornou cardeal. A tese foi convertida num dos livros mais traduzidos e exitosos de Panikkar, publicado originalmente em inglês, em $1964^{8}$.

Durante parte de seu processo de formação, Panikkar esteve ligado à Opus Dei. Entra na organização disposto "a colaborar com todo o seu ser para a edificação do reino de Deus na terra, com o entusiasmo dos jovens em sua reação ao esfacelamento da sociedade. Aceita o rigorismo da organização como um dever para modelar o próprio caráter e tornar-se um perfeito cristão" ${ }^{\prime \prime}$. Permanece ligado à organização por mais de duas décadas, dos anos 1940 a 1964, mas sua relação com a Opus Dei foi ficando aos poucos mais difícil, à medida em que avançava em sua reflexão e compromisso de vida. Passa por momentos de incompreensão e animosidade, encontrando resistências localizadas. Sua presença torna-se causa de incômodo. Vém então dispensado canonicamente de seus compromissos com a organização e incardina-se na Diocese de Varanasi (Índia).

\footnotetext{
${ }^{4}$ Ibid., p. 41. Em reflexão expressa em 2001, lembra Panikkar: "Fui educado no catolicismo de minha mãe espanhola, mas sem jamais ter deixado de permanecer unido à tolerante e generosa religião de meu pai hindu": R. PANIKKAR, "Non devo difendere la mia verità, ma viverla", Missione Oggi 4 (2001). Ver ainda: R. PANIKKAR / M. CARRARA, Pellegrinaggio al Kailâsa, Troina: Servitium, 1996, pp. 63-64.

${ }^{5}$ R. PANIKKAR, Entre Dieu et le cosmos: Entretiens avec Gwendoline Jarczyk, Paris: Albin Michel, 1998, p. 19.

${ }^{6}$ A tese foi publicada em Madri, em 1951, com posterior edição revisada em 1972.

${ }^{7}$ A tese foi publicada em Madri, em 1961, com o título: Ontonomía de la ciencia. Sobre el sentido de la ciencia y sus relaciones con la filosofía, Madrid: Gredos, 1961.

${ }^{8}$ R. PANIKKAR, The Unknown Christ of Hinduism, London: Darton Longman \& Tod, 1964 (com posteriores edições em espanhol, francês, italiano, alemão e chinês).

${ }^{9}$ PANIKKAR / CARRARA, Pellegrinaggio al Kailâsa, p. 65.
} 
Quando Panikkar doutorou-se em teologia, em 1961, já tinha feito sua primeira viagem à Índia, terra de seu pai, e isso ocorreu no final de 1954, numa missão apostólica. Passa um ano no Sul da Índia, estabelecendo-se em Varanasi. Já tinha certo domínio do sânscrito, que aprendera em Barcelona. Com 36 anos de idade vislumbrava com essa viagem o nascimento de um novo e decisivo período em sua vida e o relata de forma viva num testamento: "Parece-me necessário falar de mim uma última vez para cancelar um período de minha vida, que quase com toda certeza abarca mais da metade cronológica de minha existência terrestre... Posso dizer que começa um período novo em minha vida, com a morte real de minhas ilusões e ideais assumidos até agora..." ${ }^{10}$. Em Varanasi leva uma vida "quase monástica", estudando, meditando e escrevendo. Ocorre que um de seus textos vém descoberto por um professor de Harvard, que o convida para ser professor visitante nessa prestigiosa Universidade. Estimulado pelo bispo de Varanasi, Panikkar aceita o convite e ministra o curso em Harvard. Foi tal o sucesso alcançado, que ele vém nomeado professor por mais cinco anos. Como Panikkar não desejava deixar a Índia, acabou fazendo um contrato de permanência semestral ${ }^{11}$. Durante mais de vinte anos, Panikkar divide o seu tempo entre a Índia e os Estados Unidos. Para tecer o fio dessa complexa convivência entre cidades tão díspares como Santa Bárbara e Varanasi, tão distantes quanto ao índice de desenvolvimento humano, só mesmo uma vida interior de profundidade. E Panikkar relata a respeito: "Eu me descobri, desse modo, não entre, mas no meio do Oriente e do Ocidente, em suas respectivas versões hindu-budista e cristã-secular, que se tornaram parte do meu universo pessoal"12.

Como professor visitante, ministra cursos de religiões comparadas nas Universidades de Harvard e Califórnia, mas também atua nas Universidades de Cambridge (Inglaterra) e Montreal (Canadá). Vém nomeado, em seguida, professor catedrático de filosofia comparada das religiões e história das religiões na Universidade da Califórnia-Santa Bárbara, onde se estabelecerá entre os anos de 1971 a 1987. É com gosto que Panikkar trabalha na Universidade da Califórnia, numa década particularmente favorável para o exercício crítico e a criatividade. Ele relata a respeito:

A Califórnia é a terra do mais forte espírito crítico norte-americano; face ao conservadorismo de Boston (Universidade de Harvard), a Califórnia teve sempre uma larga tradição de abertura. Foi nela que brotou a cultura de protesto e a contracultura nos anos 60-70, os movimentos inconformistas universitários, o movimento hippie, movimentos antimilitaristas e outros movimentos radicais ${ }^{13}$.

\footnotetext{
${ }^{10}$ R. PANIKKAR, "Mi testamento", ap. PRIETO, Más allá de la fragmentación de la teología, p. 53.

${ }^{11}$ PANIKKAR, Entre Dieu et le cosmos, p. 21.

${ }^{12}$ PANIKKAR / CARRARA, Pellegrinaggio al Kailâsa, p. 69.

${ }^{13}$ Ap. PRIETO, Más allá de la fragmentación de la teología, p. 62.
} 
Na visão de Panikkar, viver na Califórnia era "estar no centro vital", e poder participar de toda renovação espiritual que ali acontecia, e também deixar-se enriquecer pela sua dinâmica intercultural e inter-religiosa, de particular abertura ao Oriente. Reconhece também o traço pioneiro das Universidades americanas no campo do estudo das religiões:

A universidade norte-americana é, possivelmente, a primeira no sentido de levar a sério, acadêmica e cientificamente, o problema religioso, na segunda metade do século XX. O estudo acadêmico das religiões deu um passo gigantesco com o aporte da Universidade norte-americana. Diferentemente das universidades europeias, onde o estudo das religiões passou quase que por esquecido ${ }^{14}$.

Em 1987, Panikkar retorna às suas raízes, na Catalunha. Deixa a Universidade de Santa Bárbara, agora como professor emérito, e passa a viver em Tavertet, um pequeno povoado da província de Barcelona (Comarca de Osona). Sem romper com suas atividades (cursos, seminários e encontros), passa a ter uma vida mais concentrada, voltada sobretudo para a meditação. É nesse vilarejo montanhoso, "envolvido por silêncio e beleza", que vive sua última etapa da vida, vindo a falecer em agosto de 2010, aos 91 anos de idade. Deixou uma vasta obra publicada, que agora vem sendo recolhida de forma sistemática pela editora Jaca Book (Itália), sob a organização de Milena Carrara Pavan. Estão previstos 18 volumes, tratando os seguintes temas: Mística e Espiritualidade (dois tomos), Religião e religiões, Cristianismo, Hinduísmo (dois tomos), Budismo, Culturas e religiões em diálogo (dois tomos), Hinduísmo e cristianismo, Visão trinitária e cosmoteândrica: Deus-Homem-Cosmo, Mistério e hermenêutica (dois tomos), Filosofia e teologia, Secularidade sagrada, Espaço, tempo e ciência, Miscelânea (Reunião de Textos), Fragmentos de um diário ${ }^{15}$.

\section{Os apelos da Índia}

O traço inter-religioso já estava impresso no coração de Panikkar. Não foi difícil para ele mergulhar corajosamente no mistério da Índia. Desde o seu primeiro contato com a Índia, no final de 1954, foi tomado por uma paixão avassaladora. Recorda em seus trabalhos que foi um dos períodos mais felizes de sua vida. Foi a oportunidade de viver a fundo a dinâmica interreligiosa e descobrir a ideia de relação, que será tão importante para ele ao

\footnotetext{
${ }^{14}$ Ibid., p. 63.

${ }^{15}$ São volumes que cobrem um grande itinerário de vida, em torno de 70 anos. Aos volumes citados vém também acrescentado um livro que expressa a síntese de seu pensamento, onde se recolhem as introduções de todos os volumes de sua obra completa (Opera Omnia): R. PANIKKAR, Vita e parola: La mia opera, Milano: Jaca Book, 2010.
} 
longo de sua trajetória. Em resposta às perguntas sobre o seu itinerário humano, respondia com tranquilidade: "Parti cristão, me descobri hindu e retornei budista, sem jamais ter deixado de ser cristão". E complementou sua reflexão mais tarde, dizendo que em seu retorno reconheceu-se um "melhor cristão"16.

Foi no desvelamento de seu itinerário de busca que Panikkar encontrou o hinduísmo e o budismo, e isto ocorreu de forma natural e sem angústia ${ }^{17}$. Reconhece que foi à Índia como um aprendiz que indaga, como alguém que se achega aos pés de um mestre:

Não fui à Índia como um professor, mas como aluno... como aquele que busca, como alguém que se senta sem dificuldade aos pés de um mestre, que aprendia a língua dos aborígenes e queria ser um deles... Isso não era uma tática, nem mesmo algo que havia planejado. Era o meu karma. Ocorreu simplesmente assim... Queria identificar-me com minha identidade hindu, e para isso não havia o que fazer senão deixá-la emergir em mim ${ }^{18}$.

A tradição hindu já era um traço familiar, que retomou com alegria. A abertura ao budismo veio na sequência, como desdobramento de um aprofundamento de sua dinâmica vital:

Minha identidade budista desenvolveu-se de outra maneira, uma vez que não havia nascido com ela. Minhas iniciações no budismo chegaram, também, de forma natural, mas foram resultado do trabalho interior, que com muita paciência e humildade assemelhava-se minutis minuendis ao Buda: a radical sensibilidade humana, ou uma experiência comparável a que os hindus e cristãos fazem do nada ${ }^{19}$.

Panikkar tem plena consciência do caráter inefável de uma experiência religiosa, de seu traço único e singular, que não pode ser comparável a outra. Há nela um mistério que é intransponível. Mesmo assim, reconhece a possibilidade de alguém falar duas linguagens experienciais, e ele mesmo é um exemplo vivo disso. Acredita ser possível alguém penetrar de modo "existencial e vital" em outras cosmovisões, de encarnar-se numa outra cultura, de penetrar sua linguagem e partilhar o seu mundo. Tudo isso de forma natural, desde que essa relação não comprometa as "próprias intuições fundamentais" 20 .

\footnotetext{
${ }^{16}$ R. PANIKKAR, Il dialogo intrareligioso, Assisi: Cittadella, 1988, p. 60; PANIKKAR, Entre Dieu et le cosmos, p. 84.

${ }^{17}$ Diferentemente de outro buscador, Henri le Saux (Abhishiktananda), a comunhão de Panikkar com o hinduísmo não foi motivo de angústia. Ele reconhece que o simultâneo sentir-se cristão e hindu, monoteísta e advaitin, não foi para ele um problema. Cf. S. BOULAY, La grotte du cœur: La vie de Swami Abhishiktananda (Henri le Saux), Paris: Cerf, 2007, p. 14

${ }^{18}$ Ap. PRIETO, Más allá de la fragmentación de la teología, p. 55.

${ }^{19}$ Ibid., pp. 55-56.

${ }^{20}$ R. PANIKKAR, L'esperienza della vita: La mistica, Milano: Jaca Book, 2005, pp. 184185.
} 
Assim como Panikkar, temos outros exemplos de místicos cristãos que ampliaram sua forma de compreender a identidade cristã, enriquecendoa com outras perspectivas religiosas, como é o caso de Henri le Saux, Thomas Merton e Louis Massignon. Alguns falam em linguagem "híbrida", outros em "bilinguismo" ou "dupla pertença". As expressões nem sempre conseguem traduzir de forma clara o que se dá na experiência viva, de cristãos que se dão conta, no exercício relacional, que a realidade do Mistério não consegue esgotar-se numa única tradição religiosa. Há, de fato, aspectos novidadeiros e inusitados nas múltiplas formas de aproximação e entendimento com Deus, que transbordam a experiência específica do cristianismo. Teólogos cristãos como Jacques Dupuis reconhecem que, apesar da dificuldade real em partilhar duas fés religiosas diversas, não se pode omitir tal possibilidade, uma vez que experiências profundas nessa direção não são raras nem desconhecidas ${ }^{21}$.

A relacionalidade é um traço tão rotineiro na vida de Panikkar, que acreditar na possibilidade de uma experiência profunda e partilhada com tradições religiosas distintas é para ele algo natural e inquestionável. Vai ainda mais longe ao sustentar que aquele que não consegue fazer tal experiência inter-religiosa, brotando do íntimo do coração, ainda que de forma incoativa, corre o risco de tornar-se um fanático. O caminho da autenticidade passa, necessariamente, pela abertura radical do coração ao mundo da diferença e da diversidade. Trata-se de uma experiência que é única e preciosa para a afirmação da identidade. Na visão de Panikkar, "aquele que não conhece senão sua religião, não a conhece verdadeiramente" 22 , daí a importância essencial do diálogo inter-religioso. É insuficiente considerar que basta fixar-se na própria tradição religiosa, aprofundando-a, para encontrar o Mistério sempre maior, que está na fonte de toda busca. Para Panikkar, tal solução é insuficiente e não convincente: "Sem um diálogo externo, ou seja, sem um intercâmbio constante com outras pessoas, as religiões afogam-se (...). Dificilmente alguém (...) poderá entender a fundo sua religião sem ter uma ideia da existência e legitimidade de outros universos religiosos ${ }^{\prime 23}$.

A pista para o encontro verdadeiro está na direção da profundidade. Não é fruto exclusivo de um trabalho racional: "É na profundidade do conhecimento obscuro da fé que as duas espiritualidades podem encontrar-se e

${ }^{21}$ J. DUPUIS, Rumo a uma teologia cristã do pluralismo religioso, São Paulo: Paulinas, 1999, p. 518; P.F. KNITTER, Introdução à teologia das religiões, São Paulo: Paulinas, 2008, pp. 357-358; Cl. GEFFRÉ, Profession théologien: Entretiens avec Gwendoline Jarczyk, Paris: Albin Michel, 1999, p. 242.

22 PANIKKAR, Entre Dieu et le cosmos, pp. 74 e 174.

${ }^{23}$ R. PANIKKAR, "Religión (Diálogo intrarreligioso)", in C. FLORISTAN / J.J. TAMAYO

(org.), Conceptos fundamentales del cristianismo, Madrid: Trotta, 1993, p. 1148. 
é ali que pode ocorrer, para as duas partes, uma real conversão" ${ }^{24}$. Serve aqui a distinção estabelecida por Panikkar entre fé e crença. Enquanto para ele a fé é sempre transcendente e aberta, não podendo ser expressa em fórmulas universais, a crença é sempre particular. Ela busca traduzir a fé no âmbito das estruturas relativas a uma dada tradição particular, mas deve estar sempre refererida ao horizonte transcendente mais amplo. A fé transcende as formulações dogmáticas das diversas tradições religiosas, mas está sempre vinculada a ideias e fórmulas, expressas nas crenças, sem, porém, identificar-se com elas em momento algum. Na medida em que a fé identifica-se cegamente com a crença, não deixando o horizonte aberto, o diálogo vém interrompido e firma-se a realidade de um exclusivismo problemático e necrófilo ${ }^{25}$.

Em sua permanência na Índia, foram decisivos os encontros com Jules Monchanin (1895-1957), Bede Griffiths (1906-1993) e em particular Henri le Saux (1910-1973). O exemplo de Abhishiktananda, como Le Saux vém nomeado, marcou profundamente Panikkar. Ele o via como um dos "espíritos ocidentais mais autênticos" no que toca ao mergulho na experiência indiana. Foi no encontro e convivência com ele que soube aprofundar-se no caminho do advaita (a-dualidade) e na experiência do diálogo com o hinduísmo, aproximando-se da "natureza abissal do encontro". Naquele final dos anos 1950 e inícios de 1960, um período marcado por tantas dificuldades e incompreensões, Panikkar e Abhishiktananda partilharam uma grande amizade e, sobretudo, comunhão. Em carta de Panikkar ao amigo falecido, na quaresma de 2005, expressa que o distanciar do tempo o fez perceber melhor o significado de sua "obstinada existência" em busca do apelo interior do atman ${ }^{26}$.

\section{Um buscador permanente}

Um dos traços que melhor define Raimon Panikkar é o de buscador permanente e apaixonado. Conjuga com sabedoria o amor à vida, a atenção ao cosmos e a abertura ao outro. Encaixa-se bem na definição que ele mesmo cunhou para o ser humano religioso: um buscador e peregrino que

${ }^{24}$ R. PANIKKAR, Il Cristo sconosciuto dell'induismo, Milano: Jaca Book, 2008, p. 129. Na visão de Panikkar, é na profundidade da experiência mística que se dá a possibilidade de harmonizar as diversas tradições religiosas, e não numa "abertura horizontal indiscriminada": S. CALZA, La contemplazione: Via privilegiata al dialogo cristianoinduista, Milano: Paoline, 2001, pp. 176-177. Ele também assinala que "só partindo do fundo mesmo do mistério, e não de suas manifestações, poderemos dizer se as outras religiões são verdadeiras ou simplesmente aparências ilusórias": R. PANIKKAR, La nuova innocenza 3, Sotto il Monte: Servitium, 1996, p. 142.

${ }^{25}$ PANIKKAR, Il dialogo intrareligioso, pp. 76, 85-87 e 110.

${ }^{26}$ R. PANIKKAR, "Préface", in BOULAY, La grotte du cœur, p. 13. 
caminha com segurança por caminhos inexplorados. Alguém que está aberto e disponível para captar a novidade do cotidiano, em cada um de seus preciosos momentos, sem deixar de lado a herança que traz em sua bagagem. Traduz fielmente a vocação monástica que é a aspiração ao simples ${ }^{27}$. O mistério para ele está em toda parte, o que se requer é saber escutar o seu canto. Há que deixar-se abandonar ao inesperado sopro da brisa, vencendo as barreiras impostas pela vontade. Há que viver, simplesmente, deixando fluir a vida em cada instante ${ }^{28}$.

O peregrino é alguém que se dispõe a "expor-se a novas paisagens", a perigos e incertezas. $\mathrm{O}$ mergulho no mundo do outro, na realidade distinta, é sempre arriscado. Panikkar fala em "salto mortal", pois envolve a totalidade da pessoa, com ameaças precisas para a sua autocompreensão. Esse caminhar faz parte da dinâmica humana:

o senso da peregrinação parece responder a uma profunda necessidade que o ser humano sente de ir além dos limites da experiência ordinária e entrar no misterioso reino do além; e os lugares de peregrinação parecem ter a força de um ímã biológico-espiritual geográfico que atrai os peregrinos para o campo de seu mistério doador de vida ${ }^{29}$.

A peregrinação verdadeira, como indica Panikkar, traduz o caminho para o núcleo da pessoa, para o seu centro. E só está preparado para realizá-la aquele que morreu para o seu "pequeno eu" e está sintonizado com o tempo e aberto para a união com o Si universal ${ }^{30}$. Em sua presença na Índia, Panikkar realizou duas importantes peregrinações espirituais: às fontes do Ganges e ao monte Kailâsa. Retoma, assim, o movimento que o povo indiano faz, a cada ano, aos seus lugares sagrados. Trata-se do deslocamento de retorno às fontes, de onde provêm todas as águas, capazes de restaurar as forças e a dinâmica vital. A peregrinação às fontes do Ganges ocorreu em junho de 1964 e Panikkar esteve acompanhado por Henri le Saux. Essa experiência inspirou um dos livros do místico catalão: Uma missa nas fontes do Ganges, cuja primeira edição ocorreu em 196731. A outra peregrinação ocorreu décadas depois, em setembro de 1994, ao monte Kailâsa, considerado como o "templo do Absoluto", e venerado pela maior parte das religiões do sul da Ásia. A narrativa dessa peregrinação está registrada em outro livro de Panikkar, Peregrinação ao Kailâsa $(2006)^{32}$. Sua companheira de viagem, Milena Carrara, pergunta ao mestre,

\footnotetext{
${ }^{27}$ Ver a respeito o belo livro de R. PANIKKAR, Éloge du simple: Le moine comme archétype universel, Paris: Albin Michel, 1995.

${ }^{28}$ PANIKKAR / CARRARA, Pellegrinaggio al Kailâsa, p. 61.

${ }^{29}$ Ch. DUQUOC / V. ELIZONDO, "Peregrinação: ritual permanente da humanidade", Concilium (Br) (1996/nº 266) 5-9, aqui p. 8.

${ }^{30}$ PANIKKAR / CARRARA, Pellegrinaggio al Kailâsa, p. 61.

${ }^{31}$ H. LE SAUX / O. BAUMER / R. PANIKKAR, Alle sorgenti del Gange: Pellegrinaggio spirituale, Milano: Cens, 1994.

${ }^{32}$ PANIKKAR / CARRARA, Pellegrinaggio al Kailâsa.
} 
a certa altura, qual a razão de considerarem alguns lugares mais sagrados, já que Deus encontra-se em toda parte. E relata sua explicação:

\begin{abstract}
Ele me explica que Deus manifesta-se mais vivamente naqueles lugares que foram carregados pela espiritualidade das grandes almas que ali viveram a sua união com Deus; estes ascetas puderam perceber em seu tempo a atração por aqueles lugares, em geral distantes, solitários, desertos, onde a sua sensibilidade soube colher vibrações particulares ou simplesmente onde o silêncio é mais absoluto, dumia, de que fala Elias na Bíblia ${ }^{33}$.
\end{abstract}

\title{
4. A intuição cosmoteândrica e a percepção do advaita
}

Em relato sobre a sua biografia, Panikkar assinala que nunca viveu uma experiência semelhante à de Paulo, na estrada de Damasco, que assinalaria um ponto preciso de conversão. Sua vida desenvolveu-se de forma intensa e crescente. Há, porém, um momento em que se dá conta de uma intuição cosmoteândrica, relacionada à sua experiência da Trindade. Percebe com clareza que toda a realidade é uma cristofania e que a Trindade constitui a resposta verdadeira de sua busca. Ao falar de intuição cosmoteândrica, faz recurso ao teandrismo da tradição ortodoxa, acrescentando toda a sua reflexão original sobre o cosmos, tão negligenciado nas espiritualidades cristãs. Na visão de Panikkar, os três elementos que compõem a visão cosmoteândrica ou teoantropocósmica - Deus, Homem e Matéria -, traduzem três "dimensões constitutivas da realidade". Não há como escapar da presença envolvente de Deus ou do divino. Ele está em todo lugar. Isso não significa, porém, assumir um panteísmo. O que ocorre é uma identificação tópica, mas o mistério transborda infinitamente tudo o que se pode pensar, ver ou imaginar.

Cosmoteândrica será, pois, esta visão, esta experiência, de que somos uma parte da Trindade, e que há três dimensões do real: uma dimensão de infinito e de liberdade, que chamamos divina; uma dimensão de consciência, que chamamos humana; e uma dimensão corporal ou material, que chamamos cosmos. Todos participamos desta aventura da realidade ${ }^{34}$.

Essas três dimensões do real estão em profunda interpenetração, expressão que traduz para hoje a ideia clássica de perichôrêsis ou circumincessio. Trata-se de uma interpenetração recíproca que não coloca em causa nenhuma das particularidades das dimensões em questão. O que vigora é a ideia de relação. Na linha dessa perspectiva indivisa da realidade, Deus não pode ser captado como puramente transcendente ou exclusivamente

\footnotetext{
${ }^{33}$ Ibid., p. 84.

${ }^{34}$ PANIKKAR, Entre Dieu et le cosmos, p. 135.
} 
imanente. Ele é simultaneamente transcendente e imanente, é "relacionalidade pura"35. A experiência de Deus acontece no dinamismo vivo que entrelaça o humano com toda a realidade:

A experiência de Deus é a raiz de toda experiência. É a experiência em profundidade de todas e cada uma das experiências humanas: do amigo, da palavra, da conversa. É a experiência subjacente a toda experiência humana: dor, beleza, prazer, bondade, angústia, frio... subjacente a toda experiência no tanto que nos descobre uma dimensão de infinito, não-finito, in-acaba$\mathrm{do}^{36}$.

Para ter acesso à imagem mais profunda da Trindade, Panikkar faz recurso a uma intuição hindu, que supera as tentações da unidade ou dualidade. Trata-se da perspectiva advaita, da a-dualidade, que indica a ausência de dualidade na estrutura própria da realidade ${ }^{37}$. $\mathrm{Na}$ linha dessa reflexão, "a divindade não está individualmente separada do resto da realidade, nem é totalmente idêntica a ela" ${ }^{38}$. A intuição advaita traduz o Mistério que preside a relação cosmoteândrica. Um mistério que não pode ser reduzido nem ao "um" ou ao "dois". É antes "a-dual", possibilitando a dinâmica viva do pluralismo. Os cristãos têm acesso a esse Mistério através de Jesus Cristo, mas outras vias possibilitam igualmente sua acolhida ${ }^{39}$.

A perspectiva advaita envolve também uma singular espiritualidade. A divindade deixa de ser percebida como um objeto, ou como um Outro, porque não há mais sujeito a fazer uma tal experiência. Para o advaitin, a divindade não é "algo" que se percebe em si ou fora de si, mas "uma luz na qual o Real é iluminado e descoberto". A contemplação emerge como "a visão da Realidade total na qual o ego (eu psicológico) enquanto tal, não tem mais nenhum lugar; é a experiência do Absoluto na sua simplicidade e na sua complexidade, alegria perfeita alcançada na en-stasi da união" ${ }^{\prime 0}$.

\footnotetext{
${ }_{35}$ Para Panikkar, a Trindade expressa uma "concepção propriamente revolucionária, na medida em que se cessa de considerar Deus como uma substância. Deus é relacionalidade pura, ou melhor, ele é uma das dimensões da relacionalidade de todo o real. É nisto que consiste, precisamente, a visão cosmoteândrica": PANIKKAR, Entre Dieu et le cosmos, p. 122.

${ }^{36}$ R. PANIKKAR, Ícones do mistério: A experiência de Deus, São Paulo: Paulinas, 2007, p. 77.

${ }^{37}$ R. PANIKKAR, Il dharma dellinduismo, Milano: Bur, 2006, pp. 171-173.

${ }^{38}$ PANIKKAR, Ícones do mistério, p. 110. O que predomina é a "inter-relação mútua entre imanência e transcendência (...). A divindade é, precisamente, esta imanência e transcendência inserida no coração de cada ser ": ibid., pp. 72-73.

${ }^{39}$ PANIKKAR, Il Cristo sconosciuto dellinduismo, pp. 54-55.

${ }^{40}$ R. PANIKKAR, Trinità ed esperienza religiosa dell'uomo, Assisi: Cittadella, 1989, p. 70. É interessante constatar a sintonia dessa reflexão de Panikkar com a tradição místico-especulativa alemã, em particular com as reflexões de Margherite Porete, Mestre Eckhart e Angelus Silesius. Para esses místicos da tradição cristã, Deus não pode ser pensado como objeto, daí a dificuldade de falar em "alteridade", pois nesse caso cai-se na determinação, e Deus não pode ser determinado, pois é infinito. Deus é visto como
} 


\section{O caminho do diálogo dialogal}

As religiões são também provocadas a viverem uma "interpenetração recíproca". É um dos temas mais presentes na reflexão de Raimon Panikkar. Trata-se do desafio de uma nova relação entre as diversas tradições religiosas, para além do exclusivismo, inclusivismo e paralelismo. O caminho revela-se na abertura para uma nova dinâmica relacional, que resguarde a particularidade de cada uma das tradições envolvidas. Não é um trajeto simples, mas importante e inevitável, doloroso mas purificador. Para que se realize com vigor requer uma mudança de compreensão e de atitude. Esse processo não é pontual, mas contínuo e progressivo, e envolve abertura e paciência. É um caminho que está sempre se fazendo. O objetivo proposto "não é chegar à completa unanimidade, ou de misturar todas as religiões, mas sobretudo comunicação, simpatia, amor, complementaridade polar $^{\prime \prime 4}$.

Em momentos diversificados, Panikkar utilizou a expressão "ecumenismo ecumênico" para traduzir esse desafio dialogal. Para além do ecumenismo tradicional, voltado para a unidade dos cristãos, aponta-se agora para um ecumenismo mais amplo, que estende a dinâmica de abertura para toda a família humana. A sua perspectiva vém definida com clareza:

O objetivo é uma melhor compreensão, uma crítica corretiva e, possivelmente, uma mútua fecundação entre as tradições religiosas do mundo, sem mitigar suas respectivas heranças ou comprometer sua possível harmonia ou as eventuais diferenças irredutíveis ${ }^{42}$.

Esse trabalho ecumênico, em sentido largo, é inesgotável e revelador de possibilidades inusitadas. Requer também muita humildade, pois deve estar animado pela consciência da contingência e do limite. Nenhuma religião é capaz de exaurir o campo da experiência humana e das manifestações do sagrado. A realidade plural está sempre aí a desafiar a compreensão humana. Há que combater incessantemente a sedução da autossuficiência e da hybris totalitária, que constituem impedimentos precisos para a abertura ao pluralismo de princípio. Esse "ecumenismo crítico exige magnanimi-

\footnotetext{
"propriamente nada" e para que a alma humana dele se aproxime, é necessário que "perca seu próprio nome", que desapareça enquanto determinada e desapegue-se radicalmente a ponto de transformar-se naquilo que ama. Ver a respeito as reflexões de Marco Vannini em: M. PORETE, Lo specchio delle anime semplice, Cinisello Balsamo: San Paolo, 1994, p. 208, n. 104; e A. SILESIUS, Il pellegrino cherubico, Cinisello Balsamo: San Paolo, 1989, p. 36.

${ }^{41}$ R. PANIKKAR, L'incontro indispensabile: Dialogo delle religioni, Milano: Jaca Book, 2001, p. 71.

${ }^{42}$ PANIKKAR, La nuova innocenza 3, p. 60.
} 
dade, serenidade, humildade e também supõe uma certa consciência mística do caráter inefável da realidade" ${ }^{\prime 3}$.

É verdade que os cristãos estão empenhados na busca da unidade, mas torna-se cada vez mais claro nesse tempo de pluralismo religioso que a unidade está sempre em processo, traduzindo um esforço comum de adentrar-se no Mistério sempre maior. Mesmo estando convictos do conteúdo fundamental de sua fé, os cristãos

não podem conhecer quais serão os ulteriores desenvolvimentos de sua Igreja; eles não têm acesso aos planos da providência divina; não devem, portanto, agarrar-se a um esquema fixo ou a uma fé congelada. Novos dogmas, formulações renovadas, evoluções reais e progressos são características constantes do cristianismo, como de todas as religiões. Ninguém sabe como o cristianismo aparecerá quando as águas da fé unirem-se às de outras religiões para formar um rio mais caudaloso, onde os povos do futuro saciarão sua sede de verdade, bondade e salvação $0^{44}$.

A perspectiva de um ecumenismo mais ecumênico aflui para um caminho de "diálogo dialogal", como gosta de expressar Panikkar. Trata-se de um diálogo mais existencial, sem a intenção de convencer ninguém, mas sobretudo compreender o outro e deixar-se enriquecer por ele. É diferente do "diálogo dialético", que expressa mais uma arena ou disputa intelectual que aponta razões e equívocos dos interlocutores ${ }^{45}$. O diálogo dialogal ou dialógico é sobretudo um "ato religioso" movido por amor. Não pode ter outra motivação senão a partilha de dons e a mútua fecundação. Ele tem o "seu próprio valor", sendo autofinalizado.

Nem todos conseguem exercitar esse dom dialogal, sobretudo nesse tempo de pluralismo moderno, onde os conhecimentos autoevidentes perdem sua plausibilidade. Peter Berger nomeia-os como "virtuosos do pluralismo", pois lidam melhor com esta perspectiva dialogal, ao contrário de tantos outros que vivem a insegurança de participarem de um "mundo confuso e cheio de possibilidades de interpretação" ${ }^{\prime 6}$. Para entrar nesse caminho

\footnotetext{
${ }^{43}$ PANIKKAR, "Religión (Diálogo intrarreligioso)", p. 1153. Panikkar insiste muito nessa dimensão contemplativa do verdadeiro ecumenismo. E adverte: "Quanto mais estamos convencidos de nossas opiniões, tanto mais seremos 'vencidos' pelo mistério que nos ultrapassa": PANIKKAR, La nuova innocenza 3, p. 64.

${ }^{44}$ PANIKKAR, Il Cristo sconosciuto dell'induismo, p. 93. Em semelhante linha de reflexão, o teólogo dominicano Christian Duquoc assinala que a "obsessão pela unidade" pode abafar o caráter enigmático que preside a assimetria das religiões. Prefere trabalhar com a metáfora da "sinfonia sempre adiada". As religiões são representadas como "lugares de múltiplas composições, cuja unidade nos escapa": Ch. DUQUOC, O único Cristo: A sinfonia adiada, São Paulo: Paulinas, 2008, p. 166.

${ }_{45}$ PANIKKAR, Entre Dieu et le cosmos, p. 149.

${ }^{46}$ P.L. BERGER / T. LUCKMANN, Modernidade, pluralismo e crise de sentido, Petrópolis: Vozes, 2004, p. 54.
} 
requer-se liberdade interior, bem como a gratuidade de viver uma experiência de partilha e busca de uma verdade que ultrapassa a consciência possível dos próprios interlocutores. Como indica Panikkar, o diálogo verdadeiro é "um ato essencialmente religioso", envolvendo a experiência da contingência, da confiança mútua e da busca comum de um Mistério que a todos transborda ${ }^{47}$. Há uma dimensão experiencial e mística do diálogo que nem sempre é levada em consideração, mas que é muito importante:

O encontro das religiões tem uma indispensável dimensão experiencial e mística. Sem uma certa experiência que transcende o reino mental, sem um certo elemento místico na própria vida, não se pode esperar superar o particularismo da própria religiosidade, e menos ainda ampliá-la e aprofundá-la, ao ser defrontado com uma experiência humana diferente ${ }^{48}$.

O diálogo inter-religioso pressupõe o diálogo intrarreligioso. É outra das teses defendidas por Panikkar. Esse diálogo intra se dá no interior mesmo das confissões religiosas. Trata-se da tomada de consciência da própria contingência, relatividade e vulnerabilidade. É o essencial "colocar-se em questão", tão bem acentuado por Agostinho: quaestio mihi factus sum (fiz de mim mesmo um problema $)^{49}$. O diálogo autêntico requer esse permanente espírito de autocrítica: "Se não descubro em mim mesmo o cético, o incrédulo, o muçulmano e tantas outras realidades, sinto-me incapaz de entrar em diálogo com os outros" ${ }^{\prime 50}$. Como mostrou com acerto Adolphe Gesché, a fé cristã tem necessidade de uma "ausência cristã", tanto diante dela como em seu próprio interior. A interface do outro ou um "lugar fora de sua residência" torna-se fundamental para a construção da própria identidade. O grande risco é manter a tradição encerrada em si mesma, sem interlocução criadora.

É evidente que é preciso ao cristianismo o sensus fidelium, o sentido da fé que os crentes têm, mas é preciso, igualmente, aquilo que chamo de sensus infidelium, o sentido que os não crentes têm das coisas deste mundo (e mesmo das coisas da fé, pelo espírito crítico que possuem), essa pars paganorum, essa parte de paganidade ao lado da pars nostra, essa parte exterior, essa 'impureza' - no sentido estabelecido anteriormente -, essa impureza da sabedoria que vem em socorro da pureza de seu profetismo, para que este não se torne paroxístico, destruidor, alucinatório ${ }^{51}$.

\footnotetext{
${ }^{47}$ PANIKKAR, Entre Dieu et le cosmos, pp. 74, 150 e 172.

${ }^{48}$ PANIKKAR, La nuova innocenza 3, p. 156.

${ }^{49}$ PANIKKAR, Il dialogo intrareligioso, pp. 114-115.

50 PANIKKAR, Entre Dieu et le cosmos, p. 161. Algo semelhante disse Thomas Merton: "Se eu me afirmo como católico simplesmente negando tudo que é muçulmano, judeu, protestante, hindu, budista etc., no fim descobrirei que, em mim, não resta muita coisa com que me possa afirmar como católico: e certamente nenhum sopro do Espírito com o qual possa afirmá-lo": T. MERTON, Reflexões de um espectador culpado, Petrópolis: Vozes, 1970, p. 166.

${ }^{51}$ A. GESCHÉ, $O$ sentido, São Paulo: Paulinas, 2005, p. 136 (e também p. 135).
} 
O diálogo é sempre uma "aventura arriscada", mas revela-se uma exigência essencial no tempo atual, condição imprescindível para a paz entre as nações. Como sustenta Panikkar, ele é um fato importante, inevitável e urgente, mas também desconcertante e perigoso, pois coloca em questão o fundamento mesmo das próprias convicções. $\mathrm{O}$ risco maior é o de perderse ou se afogar, "pois, literalmente, nesse encontro tocamos o fundo". Mas há que jogar-se na água e nadar, ainda que as pernas estremeçam e o coração vacile. Desse encontro todos saem purificados, pois ele possibilita compreender a inexaurível profundidade do ser humano e deparar-se com o misterioso enigma que pontua o mundo das diferenças ${ }^{52}$.

\section{A cristofania}

Em diversos momentos de sua reflexão, Panikkar indicou que o indispensável encontro entre as tradições religiosas envolve uma transformação na autocompreensão das religiões. Ele busca responder a tal desafio com propostas audaciosas no campo da hermenêutica cristã para o terceiro milênio. Dentre as pistas por ele abertas, insere-se a original reflexão sobre a cristofania. Argumenta que a cristologia vigente nos últimos vinte séculos é marcadamente ocidental, nascida da fé cristã em diálogo com o judaísmo, com o mundo greco-romano e, posteriormente, com a tradição germânica e a cultura islâmica. Sua proposta vai no sentido de uma maior universalização dessa perspectiva:

Depois de estar historicamente ancorado por quase dois milênios nas tradições monoteístas originadas de Abraão, o cristianismo, caso pretenda ser católico, deve meditar profundamente sobre a kenosis de Cristo e ter a coragem, como no primeiro Concílio de Jerusalém, de desvincular-se da tradição hebraica (cujo símbolo era a circuncisão) e das tradições romanas (cujo símbolo é a cultura ocidental) sem com elas romper, deixando-se fecundar pelas outras tradições da humanidade $\mathrm{e}^{53}$.

Segundo Panikkar, a experiência de Cristo feita pelos cristãos não esgota a riqueza mesma da realidade do Cristo, que na verdade é um "símbolo - que os cristãos designam com esse nome - do Mistério sempre transcendente, mas também sempre humanamente imanente ${ }^{\prime \prime 54}$. A publicação da

${ }^{52}$ PANIKKAR, La nuova innocenza 3, pp. 100-103; e PANIKKAR, L'incontro indispensabile, pp. 30 e 61.

${ }_{53}$ PANIKKAR, Il Cristo sconosciuto dell'induismo, p. 19 (em consideração feita por Panikkar no início da nova edição italiana, em 2007). Para Panikkar, esse é o grande desafio teológico do terceiro milênio, ou seja, "levar em consideração as culturas dos dois terços do mundo que não pertencem ao filão cultural greco-semítico e não veem a realidade sob a mesma luz". Trata-se de levar a sério a kenosis de Cristo, o que não significa romper com as precedentes interpretações, mas abrir-se para uma nova consciência do Mistério sempre maior (de Cristo): ibid., p. 73.

${ }^{54}$ PANIKKAR, Il dialogo intrareligioso, p. 112. 
tese doutoral de Panikkar, em 1964, sobre O Cristo desconhecido do hinduísmo, suscitou mal-entendidos, facultando uma interpretação limitada e inclusivista de seu pensamento. Em edição posterior, o autor esclareceu que, em verdade, o Cristo desconhecido do hinduísmo era também desconhecido do cristianismo histórico ${ }^{55}$. Na linha dessa reflexão, Panikkar busca acentuar a realidade de Cristo como um Mistério que envolve as duas tradições religiosas. Enquanto alguns autores utilizam expressões como "Cristo cósmico" ou "Cristo total", Panikkar prefere falar em "Cristo cosmoteândrico", ou simplesmente Cristo. Para ele, Cristo é o "símbolo de toda a realidade", e nele encontram-se contidos todos os "tesouros da divindade", os "mistérios do homem" e a "densidade do Universo" 56 .

A cristofania envolve, assim, uma abertura à realidade mais ampla do Espírito, o que implica uma abertura genuína ao diálogo com outras religiões. A confissão cristã que indica que "Jesus é o Cristo" é pertinente e legítima. De fato, é através de Jesus que os cristãos podem encontrar o Cristo. É uma confissão que reflete uma "afirmação existencial", mas que não pode ser entendida em sentido objetivante e universal. Na verdade, como mostra Panikkar, "Jesus é o Cristo, mas o Cristo não pode ser completamente identificado com Jesus" ${ }^{57}$. Isso significa que os cristãos não têm o monopólio do Cristo, que permanece, também para eles, como Mistério que sempre advém. Um Mistério que se manifesta igualmente, sob outras formas, em todas as religiões autênticas ${ }^{58}$.

\section{A mística como experiência da vida}

Um dos desafios essenciais do tempo atual é responder a um apelo que brota de todas as partes e que se relaciona com a sede radical pela transformação do significado mesmo da vida. Em seus últimos trabalhos, Panikkar dedicou-se de forma intensiva a essa reflexão, dando um espaço significativo ao tema da mística e da espiritualidade. Identificou na "mística cosmoteândrica", que envolve Deus, Homem e Mundo, o novum do terceiro milênio ${ }^{59}$. Na visão de Panikkar, a experiência mística envolve toda a realidade, mantendo-se aberta a todos os problemas humanos. É,

\footnotetext{
${ }^{55}$ R. PANIKKAR, Cristofania, Bologna: EDB, 1994, p. 26.

${ }^{56}$ R. PANIKKAR, La plénitude de l'homme, Arles: Actes Sud, 2007, p. 197.

${ }^{57}$ PANIKKAR, Cristofania, p. 17 (ver também p. 16); PANIKKAR, Il Cristo sconosciuto dell'induismo, pp. 94 e 201.

${ }^{58}$ PANIKKAR, La nuova innocenza 3, pp. 139 e 142. Assinala Panikkar: "Embora os cristãos não possam chamar Cristo com outros nomes, permanecem aspectos ou dimensões ainda desconhecidos aos cristãos, que não estão incluídos no nome de Cristo, embora a ele relacionados": ibid., p. 141.

${ }^{59}$ R. PANIKKAR, Mistica pienezza di vita, Milano: Jaca Book, 2008, p. 12 (Opera Omnia: Mistica e spiritualità, tomo 1).
} 
por excelência, a "experiência do totum", a "experiência integral da realidade". Ele faz opção pela expressão "realidade" por considerá-la menos problemática e mais neutra, com uma mais decisiva densidade ecumênica. A mística faculta, assim, um "acesso à completa realidade (chame-a Deus, o Tudo, o Nada, o Ser, ou outra coisa) que se nos apresenta na sua plenitude $(. . .)^{\prime \prime 60}$.

Panikkar sublinha que, infelizmente, o tempo contemporâneo perdeu esse senso místico da existência, fixando-se na "epidemia reinante da superficialidade". Urge recuperá-lo, para que se faculte a essencial harmonização das energias humanas em torno de valores como o Bem, a Beleza e a Verdade. A mística não implica uma fuga do mundo, ou desprezo das realidades terrestres, mas um mergulho ainda mais fundo nas entranhas do real e na tessitura do tempo. Trata-se de uma experiência pessoal, mas não individualista, cujas repercussões são vivas, propagando-se como ondas que se espalham sem cessar por todo canto. Enquanto a mística é a "experiência suprema da realidade", a espiritualidade é o "caminho para se atingir tal experiência"61.

A espiritualidade é como uma 'carta de navegação' no mar da vida do homem: a soma dos princípios que dirigem o seu dinamismo para 'Deus', dizem alguns; para uma sociedade mais justa ou para a superação do sofrimento, dizem outros. Podemos, pois, falar de espiritualidade budista, embora os budistas não falem de Deus; e também de uma espiritualidade marxista, ainda que sejam eles alérgicos à linguagem religiosa. Em seu conceito amplo, a palavra espiritualidade expressa sobretudo uma qualidade de vida, de ação, de pensamento etc., não ligada a uma doutrina, confissão ou religião determinadas, ainda que seus pressupostos sejam facilmente reconhecíveis ${ }^{62}$.

O verdadeiro contemplativo, como mostra Panikkar, é alguém marcado por intensa liberdade e pureza de coração. Está voltado atentamente para o tempo, vivendo, simplesmente, inserido na "tempiternidade", ou seja, na eternidade que se capta em cada momento temporal da existência ${ }^{63}$. Sua linguagem tem afinidade com a linguagem poética, sendo capaz de favorecer um olhar distinto sobre o real, captando o que escapa ao olhar superficial. Ele traz consigo uma fragrância contagiante, que traduz "o respiro mesmo da vida". E todo o ser vém envolvido: "Se o teu olho é simples, todo o teu corpo será luminoso".

${ }^{60}$ PANIKKAR, L'esperienza della vita, p. 59.

${ }^{61}$ R. PANIKKAR, Vita e parola: La mia opera, Milano: Jaca Book, 2010, p. 21.

${ }^{62}$ Ibid., p. 24.

${ }^{63}$ Como assinala Panikkar, "não é fugindo do tempo - uma vez admitido que seria isso possível - que o contemplativo descobre a dimensão tempiterna. Mas integrando-o completamente na dimensão vertical que constantemente entrecorta a linha horizontal do tempo. A tempiternidade não é a ausência, mas a plenitude do tempo, e esta plenitude não é, certamente, só o futuro": PANIKKAR, Mistica pienezza di vita, p. 57. 


\section{Conclusão}

Panikkar foi um dos grandes precursores do diálogo inter-religioso entre os autores cristãos. Talvez a contribuição mais decisiva que deixou como legado foi de afrouxar os nós do etnocentrismo cristão e favorecer uma nova atitude para com as outras tradições religiosas: de abertura, hospitalidade e acolhida. Mostrou com vitalidade e vigor que o verdadeiro diálogo requer dos interlocutores um profundo respeito e cuidado com o enigma do outro. No diálogo caminha-se sobre um "solo sagrado", e os interlocutores devem estar desarmados para viver a dinâmica de reciprocidade de dons que esse encontro revela e traduz. Foi um grande "virtuoso do pluralismo religioso", um assíduo defensor da diversidade irredutível e irrevogável que marca o mundo das religiões. Pontuou igualmente a centralidade da dimensão espiritual para o exercício dialogal, enfatizando a importância da humildade, do despojamento e da pureza de coração para a afirmação de uma nova disponibilidade de encontro autêntico com o diferente.

Faustino Teixeira é doutor em Teologia pela Pontifícia Universidade Gregoriana (Roma). Professor do Programa de Pós-Graduação em Ciência da Religião da Universidade Federal de Juiz de Fora (MG), Pesquisador do CNPq e Consultor do ISER Assessoria (RJ). É autor de vários livros entre os quais: A espiritualidade do seguimento, São Paulo: Paulinas, 1994; Teologia das religiões: uma visão panorâmica, São Paulo: Paulinas, 1995; Os encontros intereclesiais de CEBs no Brasil, São Paulo: Paulinas, 1996; Ecumenismo e diálogo inter-religioso, Aparecida: Santuário, 2008. Participou também na organização das seguintes obras: No limiar do mistério, São Paulo: Paulinas, 2004; Nas teias da delicadeza, São Paulo: Paulinas, 2006; Sociologia da religião, Petrópolis: Vozes, 2010, $3^{\text {a }}$ ed.; $O$ canto da unidade. Em torno da poética de Rûmî, Rio de Janeiro: Fissus, 2007 e Catolicismo plural: dinâmicas contemporâneas, Petrópolis: Vozes, 2009.

Endereço: Rua Antônio Carlos Pereira, 328 (Condomínio Tiguera)

36071-120 Juiz de Fora - MG

e-mail: faustino.teixeira@ufjf.edu.br 